\title{
Diabetic ketoacidosis as a reason for hospitalization in adult patients with any type of diabetes mellitus
}

\section{ABSTRACT}

Introduction. Diabetic ketoacidosis (DKA) is an acute complication of any type of diabetes, but most commonly is associated with type 1 diabetes mellitus (T1D). This condition is a complex metabolic disorder resulting from significant relative or absolute deficiency of insulin, which still leads to excess of mortality and health care burden.

The main aim of the study was to assess the direct cause of DKA and to determine population at-risk among patients with greater predisposition to develop DKA, in order to propose methods and range of their education in the future.

Materials and methods. This study presents a retrospective analysis of 120 cases of DKA (102 adults with diabetes) hospitalized in the Department of Internal Medicine and Diabetology at the Central Teaching Hospital of Medical University of Lodz between 2014 and 2017.

Results. $68.4 \%$ of patients with DKA were T1D and LADA, $15.0 \%$ were T2D, $5.8 \%$ presented other types of diabetes and $10.8 \%$ were de novo diabetes. The mean age was $40.5 \pm 17.7$ years, diabetes duration $11.1 \pm$ 9.74 years, $\mathrm{HbA}_{1 \mathrm{c}}$ was $11.8 \pm 2.54 \%$. The main reason for hospitalization of patients for DKA was alcohol abuse (32.5\%), followed by infection (23.4\%), discontinuation of insulin treatment due to other reasons (13.4\%), de novo diabetes (10.8\%), lack of compliance

Address for correspondence: dr n. med. Joanna Wójcik-Odyniec Klinika Chorób Wewnętrznych i Diabetologii

Uniwersytet Medyczny w Łodzi

Centralny Szpital Kliniczny UM w Łodzi

ul. Pomorska 251, 92-213 Łódź

e-mail: wojcik.joanna1@gmail.com

Clinical Diabetology 2018, 7, 5, 215-221

DOI: $10.5603 /$ DK.2018.0021

Received: 25.04 .2018

Accepted: 25.09.2018
(5.8\%), mental disorders (5.8\%) and complex causes (3.3\%). In $5.0 \%$ of patients the reason could not be determined. All patients recovered, there was no death resulting of DKA.

Conclusions. DKA occurs most frequently in T1D, but may be associated with type 2 or other types of diabetes. Most of our patients had a history of longterm poor control of diabetes. In many cases DKA, e.g. resulting from alcohol abuse or lack of compliance, probably can be avoided when proper patient education was given. (Clin Diabetol 2018; 7, 5: 215-221)

Key words: diabetic ketoacidosis, reasons for hospitalization, diabetes, compliance, alcohol abuse

\section{Introduction}

Diabetic ketoacidosis (DKA) is still the most common, directly life-threatening complication of diabetes, despite the advances in medical care. Because of lack of central register of acute complications associated with hyperglycemia in Poland, there is no possibility of an objective assessment of the scale of this phenomenon in the whole country [1]. Okulewicz-Morawska and Krzymien reported 172 hospitalizations due to DKA (within the years 2003-2012) among patients with different types of diabetes in Warsaw [2]. Kaplon et al. observed that there were 91 T1D patients admitted to the hospital with DKA (between 2008-2011 years) in Poznan [3]. Data from England reveal that acute hyperglycemic episodes occur in 13.6 per 1000 T1D patients per year [4]. Systematic review of 8 original publications from Germany, Canada and USA demonstrated that hospitalization ratio of T1D patients due to DKA between 2000-2016 was 0-263 per 1000 PYs [5]. Still between 2000-2009 moderate fall, followed by an increase in frequency of hospitalization due to DKA 
in USA was reported. The same pattern was observed in England - frequency of hospitalization due to DKA among T1D and T2D patients was increasing between 1998-2007, then after a stabilization period, increased again in 2013 [6-8].

Diabetic ketoacidosis develops not only in patients with T1D, but may also occur in patients with T2D who cease insulin administration or provide it in an inadequate dose, and in others specific types of diabetes (particularly in the course of pancreatic disease $[9,10]$ ).

The mortality rate of DKA was almost $100 \%$ in 1922 , before implementation of insulin as a treatment for diabetes, about $29 \%$ in 1950s, and it dropped down to $15 \%$ nowadays [11]. In the 1970 s, mortality rate from ketoacidosis was around $10 \%$ in developed countries, with further data showing that mortality in highly specialized centers did not exceed $5 \%$, and was higher among older people and those with other chronic diseases [12]. Observation of 278 admissions in five Birmingham hospitals from 2000 to 2009, reveal that $1.8 \%$ patients died because of DKA [13]. Danish study (4807 admissions due to DKA between 1996 and 2002) reported an overall DKA-related mortality rate at $4 \%$, while in the group of patients above 70 years it was almost 4 times higher (15\%) [14].

Discrepancies between results of the studies cited above are due to differences between studied populations, type of diabetes, medical centers, age of patients, country and others. Despite the advances in medical care and development of new technologies, DKA still remains a significant individual and health system problem.

\section{Aim}

The aim of the study was to determine the direct reasons of DKA in patients with diabetes to identify patients who are at high risk of this acute, life-threatening complication, in order to focus on the prevention of DKA and on an educational program.

\section{Material and methods}

The study covers retrospective analysis of medical records of patients hospitalized in the Department of Internal Diseases and Diabetology at Central Teaching Hospital of Medical University of Lodz between 2014-2017. During this time 102 adult diabetic patients with 120 cases (including 12 patients with recurrent DKA) with documented clinical status and laboratory tests (serum glucose concentration $>250 \mathrm{mg} / \mathrm{dl}$, blood $\mathrm{pH}<7.3$, serum bicarbonate $<15 \mathrm{mmol} / \mathrm{l}$, presence of urine or serum ketones, anion gap > $12 \mathrm{mmol} / \mathrm{l}$ ) confirming DKA were hospitalized [15].
The following anthropometric, clinical and laboratory data were collected: age, sex, type of diabetes, duration of the disease, regiment of medical treatment, history of the DKA episodes, serum glucose concentration on admission, blood $\mathrm{pH}$ and the $\mathrm{HbA}_{1 \mathrm{c}}$ level. The reasons of the DKA were assessed according to doctors' diagnosis. For the purpose of the study, the population was divided into the following categories in terms of the direct cause of the DKA: alcohol abuse, infections, newly diagnosed diabetes (no history of diabetes before the onset of DKA), lack of compliance (failure to comply with the recommended treatment), mental disorders, discontinuation of insulin administration for other reasons, complex cause (more than one of mentioned above reasons) and unknown reason. The most common mental disorders were depression, mental retardation, addiction to psychoactive substances and dementia. Lack of compliance was mainly related with the administration of lower doses of insulin (usually in fear of hypoglycemia), inability to adjust insulin dose to a specific meal, physical activity and actual glucose level, or skipping insulin injection. A significant deficiency of insulin most often occurred as a result of infections, during which insulin requirements increase and the usual doses become insufficient. All the above-mentioned causes consequently lead to situations in which insulin therapy was neglected. The group of the patients with more than 1 DKA episode within 3 years was created. The obtained data were statistically analyzed. Descriptive statistics were used to characterize the clinical group. The data with normal distribution are presented as mean values \pm standard deviation (mean $\pm S D$ ).

\section{Results}

For the purpose of the study every DKA hospitalization was treated as a separate case. All analyzed patients were hospitalized at the Department of Internal Diseases and Diabetology and all of them declared that they had no other events of DKA during the study time.

The study group comprised of 82 patients (68.4\%) with T1D. In additional 13 subjects (10.8\%) DKA was the first manifestation of T1D, 18 (15.0\%) were T2D and 7 patients (5.8\%) have diabetes with known etiology (secondary to chronic pancreatitis). $61.7 \%$ of patients were men. Detailed characteristic of study group is presented in Tables 1 and 2.

Detailed analysis of medical and diagnostic data and reasons for DKA occurrence depending on the type of diabetes are presented in Tables 3 and 4.

In 13 patients the serum glucose concentration on admission was $\geq 1000 \mathrm{mg} / \mathrm{dl}$. Recurrent episodes 
Table 1. Characteristic of the study group

\begin{tabular}{|c|c|}
\hline Number of hospitalizations (n) (\%) & $120(100)$ \\
\hline Age (years) (mean $\pm S D)(\min .-\max )$. & $40.5 \pm 17.7(19-90)$ \\
\hline \multicolumn{2}{|l|}{$\operatorname{Sex}(n)(\%):$} \\
\hline $\mathrm{F} / \mathrm{M}$ & $46(38.3) / 74(61.7)$ \\
\hline $\begin{array}{l}\text { Duration of diabetes (de novo cases } \\
\text { excluded) (years) (mean } \pm \text { SD) } \\
\text { (min.-max.) }\end{array}$ & $11.1 \pm 9.74(1-50)$ \\
\hline \multicolumn{2}{|l|}{ Diabetes (n) (\%): } \\
\hline T1D (included LADA) & $82(68.4)$ \\
\hline $\mathrm{T} 2 \mathrm{D}$ & $18(15.0)$ \\
\hline Other specific types & $7(5.8)$ \\
\hline De novo (T1D) & $13(10.8)$ \\
\hline \multicolumn{2}{|l|}{ Diabetes treatment before DKA $(n)(\%)$ : } \\
\hline $\begin{array}{l}\text { No hypoglycemic treatment } \\
\text { (diabetes de novo) }\end{array}$ & $13(10.8)$ \\
\hline 3 or more insulin injections/day & $88(73.3)$ \\
\hline 1 or 2 insulin injections/day & $2(1.7)$ \\
\hline Oral hypoglycemic agents (only) & $8(6.7)$ \\
\hline Personal pump therapy & $2(1.7)$ \\
\hline No data about pre-hospital treatment & $3(2.5)$ \\
\hline Other treatment patterns* & $4(3.3)$ \\
\hline $\mathrm{HbA}_{1 \mathrm{c}}(\%)($ mean $\pm \mathrm{SD})(\min .-\max )$. & $\begin{array}{l}11.8 \pm 2.54 \\
(7.2-19.7)\end{array}$ \\
\hline \multicolumn{2}{|l|}{ DKA indicators (on admission) } \\
\hline $\begin{array}{l}\text { Serum glucose concentration [mg/dl] } \\
\text { (mean } \pm \text { SD) (min.-max.) }\end{array}$ & $\begin{array}{l}648 \pm 232 \\
(256-1257)\end{array}$ \\
\hline $\mathrm{pH}(\operatorname{mean} \pm \mathrm{SD})(\min .-\max )$. & $\begin{array}{l}7.09 \pm 0.14 \\
(6.63-7.29)\end{array}$ \\
\hline
\end{tabular}

*Meal-related insulin treatment, 1 injection of premixed insulin, long lasting insulin + SGLT2 inhibitor

Table 2. The main reason for of DKA, determined according to doctor's diagnosis

\begin{tabular}{lc}
\hline Reasons for hospitalizations for DKA (n) (\%) & $120(100)$ \\
Alcohol abuse & $39(32.5)$ \\
$\begin{array}{l}\text { Infections (including urinary and respiratory } \\
\text { system infections and other) }\end{array}$ & $28(23.4)$ \\
$\begin{array}{l}\text { Discontinuation of insulin treatment due to } \\
\text { other reasons }\end{array}$ & $16(13.4)$ \\
Diabetes de novo & $13(10.8)$ \\
Lack of compliance & $7(5.8)$ \\
Mental disorders & $7(5.8)$ \\
Complex cause (more than one of above) & $4(3.3)$ \\
Reason unknown & $6(5.0)$ \\
\hline
\end{tabular}

of the DKA over three years were the cause of multiple hospitalizations for 12 people, mainly in men (66.7\%), a total of 29 cases. 1 men with T1D was treated for DKA 5 times and the reason each time was alcohol abuse; 2 men 3 times; 9 people twice. In this group, most cases were T1D (66.7\%). All of these people were treated with insulin, and the most common reason for repeated hospitalizations due to DKA was alcohol abuse (62.0\%). The distribution of data of recurrent episodes of DKA is presented in Table 5.

\section{Discussion}

The most common direct cause for admission to the hospital due to diabetic DKA as well as recurrent DKA episodes between 2014 and 2017 at the Internal Diseases and Diabetology Department at the Educational Center of Medical University of Lodz was alcohol abuse and its behavioral consequences. Herman et al. analyzed data of 29630 patients with T1D (aged between 12-29) in Germany and Austria, showing that $10.8 \%$ patients were regular alcohol consumers. The number of patients declaring regular alcohol consumption, as well as the amount of alcohol consumed, increased with age of subjects and was higher in men than in women [16]. In our study alcohol abuse was the main reason for hospitalization due to DKA among T1D (35.4\%), while in the Poznan and Warsaw center it was $10.0 \%$ and $16.0 \%$ respectively $[2,3]$. In our study we found that more men than women $(61.7 \%$ vs. 38.3\%) with T1D were hospitalized due to DKA. This is in agreement with the data from Poznan center (51.6\% men vs. $48.4 \%$ women) and opposite to Warsaw center $(37.4 \%$ vs. $62.6 \%$ respectively). The reason for these differences are not clear, but they are most likely reflecting the differences in demographic structure and ethnographic background.

Significant amount of data supports the correlation between more frequent alcohol consumption and deterioration of glycemic control, in particular with increased DKA risk. This also applies to patients with diabetes with known etiology (patients with pancreatitis), where alcohol causes pancreatic damage mainly as a result of direct toxicity on pancreatic beta cells, as well as rheological properties and secretion of pancreatic enzymes [17-21].

Behavioral therapy is necessary during treatment for all patients with diabetes of any age. Avoiding alcohol consumption is an important element of therapy that improves control of diabetes. Diabetes Poland recommends that daily level of alcohol consumption should not exceed $20 \mathrm{~g}$ for woman and $30 \mathrm{~g}$ for man [15]. Patients suffering from pancreatitis with dyslipi- 
Table 3. Subgroups characteristic according to the type of diabetes

\begin{tabular}{|c|c|c|c|c|}
\hline Parameter & $\begin{array}{l}\text { Diabetes } \\
\text { de novo } \\
(n=13)\end{array}$ & $\begin{array}{c}\text { T1D } \\
\text { (included LADA) } \\
(n=82)\end{array}$ & $\begin{array}{c}\text { T2D } \\
(n=18)\end{array}$ & $\begin{array}{l}\text { Other types } \\
\text { of diabetes } \\
\quad(n=7)\end{array}$ \\
\hline \multicolumn{5}{|l|}{ Age (years) } \\
\hline$($ mean $\pm S D)$ & $36.3 \pm 13.88$ & $37.4 \pm 14.48$ & $66.7 \pm 14.35$ & $40.1 \pm 9.01$ \\
\hline$(\min .-\max )$. & $(19-58)$ & $(19-85)$ & $(43-90)$ & $(29-54)$ \\
\hline \multicolumn{5}{|l|}{$\operatorname{Sex}(n)(\%)$} \\
\hline$(\mathrm{F} / \mathrm{M})$ & $4(31.0) / 9(69.0)$ & $26(32.0) / 56(68.0)$ & $15(83.0) / 3(17.0)$ & $1(14.0) / 6(86.0)$ \\
\hline \multicolumn{5}{|c|}{ Duration of diabetes (years) } \\
\hline$($ mean $\pm S D)$ & - & $11.8 \pm 10.26$ & $15.0 \pm 4.55$ & $3.3 \pm 1.53$ \\
\hline$(\min .-\max )$. & & $2-50$ & $5-25$ & $2-5$ \\
\hline \multicolumn{5}{|l|}{$\mathrm{HbA}_{1 \mathrm{c}}(\%)$} \\
\hline$($ mean $\pm S D)$ & $14.1 \pm 2.73$ & $11.4 \pm 2.41$ & $11.7 \pm 2.00$ & $11.1 \pm 1.58$ \\
\hline (min.-max.) & $(9.7-19.7)$ & $(7.2-15.6)$ & $(8.7-15.4)$ & $(9.0-14.0)$ \\
\hline
\end{tabular}

Table 4. Reasons of DKA according to the type of diabetes

\begin{tabular}{|c|c|c|c|c|}
\hline \multirow[t]{2}{*}{ Reasons of DKA } & \multicolumn{4}{|c|}{ Type of diabetes } \\
\hline & $\begin{array}{l}\text { Diabetes de novo } \\
\begin{array}{c}\text { (T1D) }(n=13) \\
n(\%)\end{array}\end{array}$ & $\begin{array}{c}\text { T1D } \\
(n=82) \\
n(\%)\end{array}$ & $\begin{array}{c}\text { T2D } \\
(n=18) \\
n(\%)\end{array}$ & $\begin{array}{c}\text { Other types of } \\
\text { diabetes }(n=7) \\
n(\%)\end{array}$ \\
\hline Alcohol abuse & - & $29(35.4)$ & $5(27.8)$ & $5(71.4)$ \\
\hline $\begin{array}{l}\text { Infections (including urinary and respiratory system infections } \\
\text { and others) }\end{array}$ & - & $18(22.0)$ & $8(44.3)$ & $2(28.6)$ \\
\hline Discontinuation of insulin treatment due to other reasons & - & $14(17.1)$ & $2(11.1)$ & - \\
\hline Lack of compliance & - & $6(7.3)$ & $1(5.6)$ & - \\
\hline Mental disorders & - & $7(8.5)$ & - & - \\
\hline Complex cause (more than one of above) & - & $3(3.6)$ & $1(5.6)$ & - \\
\hline Reason unknown & - & $5(6.1)$ & $1(5.6)$ & - \\
\hline
\end{tabular}

demia (hypertriglyceridemia) or neuropathy shouldn't drink alcohol at all [22]. According to data from Central Statistics Office this problem affects more men than women - the same pattern is present in our study group [23].

Interestingly, in our study lower level of glycated hemoglobin was found, although no statistical significance, in group with recurrent DKA (Table 5). This may be connected with eating habits, including malnutrition, because the main reason for recurrent hospitalization was alcohol abuse.

All patients with diabetes should be educated about consequences of occasional and excessive alcohol consumption, and train how to reduce the risk of acute complication, either with hyperglycemia or with hypoglycemia as it was suggested by many authors [1, $3,11]$. Diabetic patients declaring alcohol consumption should be particularly aware, and efforts should be undertaken to educate them about potential risk and complications. Psychological support can help overcome alcohol addiction.

Different kind of infections e.g.: pneumonia, diabetic foot syndrome, caries, urinary tract infections are the common reason for decompensation of diabetes, particularly in elderly patients. They also may be responsible for the creation of DKA [23-26]. In the population studied by us, infections were the main reason for DKA-related hospitalizations among T2D (Table 3).

DKA could also result from gastrointestinal infections, accompanied by vomiting and diarrhea. Patients with this condition, due to weakness as well as changes in food intake, avoid insulin injections or completely discontinue treatment. It is very important to quickly identify the infection and initiate proper treatment (fluid therapy, antibiotic therapy, patient monitoring) and to accurately educate patients how they should 
Table 5. Detailed description of the study group with more than 1 DKA episode in 3 years

\begin{tabular}{lc}
\hline Number of subjects $(\mathrm{n})(\%)$ & $12(100)$ \\
Number of hospitalizations $(\mathrm{n})$ & 29 \\
Type of diabetes $(\mathrm{n})(\%):$ & $8(66.7)$ \\
T1D & $1(8.3)$ \\
T2D & $3(25.0)$ \\
Other types of DM & $40.8 \pm 16.6(2-9)$ \\
Age (years) (mean \pm SD) (min.-max.) & $4(33.3) / 8(66.7)$ \\
Sex (n) $(\%):$ & $10.9 \pm 2.15(8.6-14.6)$ \\
F/M & $701 \pm 231(354-1129)$ \\
Mean HbA 1 (\%) (mean \pm SD) (min.-max.) & $7.05 \pm 0.13(6.82-7.28)$ \\
DKA indicators (on admission): & $18(62.0)$ \\
Serum glucose concentration [mg/dl] (mean \pm SD) (min.-max.) \\
pH (mean \pm SD) (min.-max.) & $6(20.7)$ \\
Causes of recurrent DKA ( $\mathrm{n})(\%):$ & $3(10.3)$ \\
Alcohol abuse & $1(3.4)$ \\
Infections & $1(3.4)$ \\
Discontinuation of insulin treatment due to other reasons & \\
Lack of compliance & \\
Mental disorders & \\
\hline
\end{tabular}

deal with such situations in order to minimize the risk of DKA.

The public awareness of early signs of diabetes is increasing. Social campaigns and access to various media, including the internet, allow to pay attention to certain symptoms that are characteristic for diabetes, namely polyuria, polydipsia, weight loss, weakness and increased drowsiness. However, there are still cases of DKA associated with delayed diagnosis of the diabetes. According to published data, this applies to up to 20-30\% of DKA cases [27-29].

In the analyzed group in our center only $10.8 \%$ DKA cases was a first manifestation of T1D (Table 1). In Poznan delayed diagnosis of diabetes mellitus was the cause of almost every fourth hospitalization due to DKA, and in Warsaw the percentage varied from 17 to $23 \%$ depending on the type of diabetes. However, these data can't be directly compared due to the different methodology of the study. As with the frequency of occurrence of DKA in our population, our data do not reflect the problem of too late diagnosis in the studied populations.

The main reason for the lack of compliance among patients is low awareness of the role and importance of glycemic self-control, regular insulin injections, dietary recommendations and physical activity in the treatment of diabetes. Very important aspect of the treatment of diabetes is the proper education as well as frequent reeducation of patients. Many patients do not realize that many complications, for example cardiovascular, neurological end others can be a result of inadequate treatment of diabetes. It is worth taking time to properly train patients in various aspects of the disease, in order to reduce the risk either of DKA episodes or chronic complications in the future.

Special attention should also be paid to people with mental disorders. In this group mental health problems could be the reason for clinical occurrence of DKA. The incidence of depression in diabetic patients is higher than in general population and occurs more often in women than in man [30]. Our study find 7 cases $(5.8 \%)$ of mental disorders: depressive syndrome, mental retardation, addiction to psychoactive substances and dementia. Due to the lack of physical activity, improper diet, smoking, obesity, a tendency to neglect self-control and treatment, this particular group of patients is predisposed to develop complications, including DKA. Depression disorders also have a direct negative impact on glucose metabolism, including increased secretion of counter-regulating hormones, glucose transport disorders and increased activity of inflammatory factors, which contribute to the increase in insulin resistance [31]. In order to prevent DKA in this group of patients, it is necessary to pay attention, if 
possible, to the exact education of the family and care providers of these patients. It should be mentioned that DKA may be also develop in patients who have eating disorders, including anorexia and bulimia [32, 33], however, we did not observe this problem in adult population in our study.

Our study shows that DKA remains a medical problem in adult patients with diabetes, regardless of type of diabetes, sex, age and duration of the disease. In our opinion neither advanced diagnostic methods, nor modern methods of treatment can, therefore, replace the basic education of patients. Our analysis allows to establish risk factors or predictors of DKA. Patients with these factors should have our attention and time to proper training in the field of diabetes complications. None of the treatment methods will improve control of diabetic alignment if people with diabetes refuse to cooperate with the treatment team members, do not maintain systematic self-control, insulin therapy, and also do not care about the optimal diet and appropriate physical activity.

\section{Summary and conclusions}

Metabolic acidosis most commonly occurred in patients with T1D, but may happen also in T2D or other type of diabetes. In the period immediately preceding the DKA episode, almost all patients had insufficient control of their diabetes, as evidenced by high percentages of $\mathrm{HbA}_{1 \mathrm{c}}$. The most frequent reason was alcohol abuse, followed with infections and discontinuation of insulin treatment. Other causes were newly diagnosed diabetes, lack of compliance and mental disorders. The main reason for recurrent DKA episodes was alcohol abuse. Many cases of DKA (e.g. resulting from alcohol abuse or lack of compliance) could be avoided with an education and proper compliance.

\section{REFERENCES}

1. Zozulińska-Ziółkiewicz D, Wierusz-Wysocka B. Leczenie ostrych stanów hiperglikemicznych - aktualne spojrzenie na stary problem. Clin Diabet. 2013; 2(3): 104-111.

2. Okulewicz-Morawska M, Krzymień J. Kwasica ketonowa - 10 lat obserwacji. Terapia. 2014; 1(299): 44-47.

3. Kapłon M, Balawajder K, Niedźwiecki P, et al. Analiza czynników sprawczych cukrzycowej kwasicy ketonowej u osób dorosłych z cukrzycą typu 1. Clin Diabet. 2013; 2(6): 200-207.

4. Hansen TK, Møller N. Acute metabolic complications of diabetes: diabetic ketoacidosis and hyperosmolar hyperglycemia. In: Holt RIG, Cockram C, Flyvbjerg A, Goldsteing BJ. ed. Textbook of diabetes, 4th edition. Wiley 2010: 546-552.

5. Fazeli Farsani S, Brodovicz K, Soleymanlou N, et al. Incidence and prevalence of diabetic ketoacidosis (DKA) among adults with type 1 diabetes mellitus (T1D): a systematic literature review. BMJ Open. 2017; 7(7): e016587, doi: 10.1136/bmjopen-2017-016587, indexed in Pubmed: 28765134.
6. Hall MJ, DeFrances CJ, Williams SN, et al. National Hospital Discharge Survey, 2007. Natl Health Stat Report. 2010(29): 1-24, doi: 10.3886/icpsr28162.v1, indexed in Pubmed: 21086860.

7. Benoit SR, Zhang Y, Geiss LS, et al. Trends in Diabetic Ketoacidosis Hospitalizations and In-Hospital Mortality — United States, 2000-2014. MMWR Morb Mortal Wkly Rep. 2018; 67(12): 362-365, doi: 10.15585/mmwr.mm6712a3, indexed in Pubmed: 29596400.

8. Zhong VW, Juhaeri J, Mayer-Davis EJ. Trends in Hospital Admission for Diabetic Ketoacidosis in Adults With Type 1 and Type 2 Diabetes in England, 1998-2013: A Retrospective Cohort Study. Diabetes Care. 2018; 41(9): 1870-1877, doi: 10.2337/dc17-1583, indexed in Pubmed: 29386248.

9. Umpierrez GE, Smiley D, Gosmanov A, et al. Ketosis-prone type 2 diabetes: effect of hyperglycemia on beta-cell function and skeletal muscle insulin signaling. Endocr Pract. 2007; 13(3): 283-290, doi: 10.4158/EP.13.3.283, indexed in Pubmed: 17599861.

10. Fernandez R, Misra R, Nalini R, et al. Characteristics of patients with ketosis-prone diabetes (KPD) presenting with acute pancreatitis: implications for the natural history and etiology of a KPD subgroup. Endocr Pract. 2013; 19(2): 243-251, doi: 10.4158/ /EP12287.OR, indexed in Pubmed: 23529349.

11. Sieradzki J, Karnafel W, Krzymien J. Ostre zaburzenia metaboliczne w cukrzycy. Cukrzyca. In: Sieradzki J. ed. Cukrzyca, t. 2. Via Medica, Gdańsk 2016: 631

12. Malone ML, Gennis V, Goodwin JS. Characteristics of diabetic ketoacidosis in older versus younger adults. J Am Geriatr Soc. 1992; 40(11): 1100-1104, doi: 10.1111/j.1532-5415.1992.tb01797.x indexed in Pubmed: 1401693.

13. Wright J, Ruck K, Rabbitts $R$, et al. Diabetic ketoacidosis (DKA) in Birmingham, UK, 2000-2009: an evaluation of risk factors for recurrence and mortality. Br J Diabetes Vasc Dis. 2009; 9(6): 278-282, doi: 10.1177/1474651409353248.

14. Henriksen OM, Røder ME, Prahl JB, et al. Diabetic ketoacidosis in Denmark Incidence and mortality estimated from public health registries. Diabetes Res Clin Pract. 2007; 76(1): 51-56, doi: 10.1016/j.diabres.2006.07.024, indexed in Pubmed: 16959363.

15. Zalecenia kliniczne dotyczące postępowania u chorych na cukrzycę 2018. Stanowisko Polskiego Towarzystwa Diabetologicznego. Diab Prakt. 2018; 4(1): 1.

16. Hermann JM, Meusers M, Bachran R, et al. DPV initiative. Self-reported regular alcohol consumption in adolescents and emerging adults with type 1 diabetes: A neglected risk factor for diabetic ketoacidosis? Multicenter analysis of 29630 patients from the DPV registry. Pediatr Diabetes. 2017; 18(8): 817-823, doi: 10.1111/pedi.12496, indexed in Pubmed: 28145026.

17. Niebisz A, Pladzyk K, Jasik M, et al. Zaburzenia gospodarki węglowodanowej a przewlekłe zapalenie trzustki. Diabetologia Praktyczna. 2005; 6(1): 15-20.

18. Tattersall SJN, Apte MV, Wilson JS. A fire inside: current concepts in chronic pancreatitis. Intern Med J. 2008; 38(7): 592-598, doi: 10.1111/j.1445-5994.2008.01715.x, indexed in Pubmed: 18715303.

19. Vonlaufen A, Wilson JS, Pirola RC, et al. Role of alcohol metabolism in chronic pancreatitis. Alcohol Res Health. 2007; 30(1): 48-54, indexed in Pubmed: 17718401

20. Apte MV, Wilson JS. Alcohol-induced pancreatic injury. Best Pract Res Clin Gastroenterol. 2003; 17(4): 593-612, doi: 10.1016/s15216918(03)00050-7, indexed in Pubmed: 12828957.

21. Lerch $M M$, Albrecht $E$, Ruthenbürger $M$, et al. Pathophysiology of alcohol-induced pancreatitis. Pancreas. 2003; 27(4): 291-296, doi: 10.1097/00006676-200311000-00003, indexed in Pubmed: 14576489.

22. Kitabchi $A E$, Umpierrez GE, Murphy MB, et al. Management of hyperglycemic crises in patients with diabetes. Diabetes Care. 2001; 24(1): 131-153, doi: 10.2337/diacare.24.1.131, indexed in Pubmed: 11194218.

23. Zdrowie i zachowanie zdrowotne mieszkańców Polski w świetle Europejskiego Ankietowego Badania Zdrowia (EHIS) 2014 r. GUS Warszawa 2015. 
24. Trachtenbarg DE. Diabetic ketoacidosis. Am Fam Physician. 2005; 71(9): 1705-1714, doi: 10.18578/bnfc.285931452, indexed in Pubmed: 15887449.

25. Kitabchi $A E$, Umpierrez GE, Murphy MB, et al. Hyperglycemic crises in adult patients with diabetes: a consensus statement from the American Diabetes Association. Diabetes Care. 2006; 29(12): 2739-2748, doi: 10.2337/dc06-9916, indexed in Pubmed: 17130218.

26. Gupta S, Koirala J, Khardori R, et al. Infections in diabetes mellitus and hyperglycemia. Infect Dis Clin North Am. 2007; 21(3): 617-638, doi: 10.1016/j.idc.2007.07.003, indexed in Pubmed: 17826615.

27. Musey VC, Lee JK, Crawford R, et al. Diabetes in urban African-Americans. I. Cessation of insulin therapy is the major precipitating cause of diabetic ketoacidosis. Diabetes Care. 1995; 18(4): 483-489, doi: 10.2337/diacare.18.4.483, indexed in Pubmed: 7497857.

28. Randall L, Begovic J, Hudson M, et al. Recurrent diabetic ketoacidosis in inner-city minority patients: behavioral, socioeconomic, and psychosocial factors. Diabetes Care. 2011; 34(9): 1891-1896, doi: 10.2337/dc11-0701, indexed in Pubmed: 21775761.

29. Bell DS, Alele J. Diabetic ketoacidosis. Why early detection and aggressive treatment are crucial. Postgrad Med. 1997; 101(4):
193-204, doi: 10.3810/pgm.1997.04.203, indexed in Pubmed: 9126212.

30. Anderson RJ, Freedland KE, Clouse RE, et al. The prevalence of comorbid depression in adults with diabetes: a meta-analysis. Diabetes Care. 2001; 24(6): 1069-1078, doi: 10.2337/diacare.24.6.1069, indexed in Pubmed: 11375373.

31. Musselman DL, Betan E, Larsen $\mathrm{H}$, et al. Relationship of depression to diabetes types 1 and 2: epidemiology, biology, and treatment. Biol Psychiatry. 2003; 54(3): 317-329, doi: 10.1016/s00063223(03)00569-9, indexed in Pubmed: 12893107.

32. Talbot F, Nouwen A. A review of the relationship between depression and diabetes in adults: is there a link? Diabetes Care. 2000; 23(10): 1556-1562, doi: 10.2337/diacare.23.10.1556, indexed in Pubmed: 11023152.

33. Scheuing N, Bartus B, Berger G, et al. DPV Initiative, German BMBF Competence Network Diabetes Mellitus. Clinical characteristics and outcome of 467 patients with a clinically recognized eating disorder identified among 52,215 patients with type 1 diabetes: a multicenter German/Austrian study. Diabetes Care. 2014; 37(6): 1581-1589, doi: 10.2337/dc13-2156, indexed in Pubmed: 24623022. 